\title{
The Use of Wall Charts in Instruction to Improve the Eighth Grade Students' Vocabulary Mastery (An Experimental Study at SMP Negeri 4 Banda Aceh)
}

\author{
Nora Fitria ${ }^{1, a}$, Samsu Ali ${ }^{1, b}, \&$ T.M. Rafsanjani ${ }^{2, a^{*}}$ \\ 1Department of English Education, Faculty of Teacher Training and Education, Universitas Serambi Mekkah, Banda Aceh, 23245, Indonesia. \\ ${ }^{2}$ Faculty of Public Health Universitas Serambi Mekkah, Banda Aceh, 23245, Indonesia. \\ anorafitria@serambimekkah.ac.id, btmrafsanjani@serambimekkah.ac.id \\ ${ }^{*}$ Corresponding Author \\ Whatsapp Number [085310750403]
}

How to Cite : Fitria, N., Ali, S., \& Rafsanjani, T.,M. (2020). The Use of Wall Charts in Instruction to Improve the Eighth Grade Students' Vocabulary Mastery (An Experimental Study at SMP Negeri 4 Banda Aceh). International Journal for Educational and Vocational Studies, 2 (8), 726-730. DOI: https://doi.org/10.29103/ijevs.v2i8.2689

\section{ARTICLE HISTORY}

Received: 6 July 2020

Revised: 10 July 2020

Accepted: 16 July 2020

\section{KEYWORDS}

Vocabulary Mastery;

Wall Charts;

Learning Instruction;

\begin{abstract}
The study was aimed to find out if there is a significant difference between the eighth grade students of SMP Negeri 4 Banda Aceh who are taught vocabulary by using wall chart and those who are taught without using wall chart. The experiment was from conducted from from March 5th, 2018 to May 8th, 2018. 2018 at SMP Negeri 4 Banda Aceh. This study is conducted by using quantitative research and in this case is an experimental study. The population of this study is all students of the eighth grade students of SMP Negeri 4 Banda Aceh in academic year 2017/2018. The total population is 115 students who are composed of five classes; class VIII1, class VIII2, class VIII3, class VIII4, and class VIII5. While the sample of this study is taken from two classes of the five classes. One class is as an experimental group and one another is as control group. In this study, the students of class VIII5 are taken as experimental group and the students of class VIII4 are taken as control group. Every group consists of 30 students thus the total sample is 60 . Choosing class as experimental and control group is done randomly. The data were gotten through test; pre-test and post test. The data were analyzed by using SPSS 18.0. The result of the study shows that there is a significant difference between the eighth grade students of SMP Negeri 4 Banda Aceh who are taught vocabulary by using wall chart and those who are taught without using wall chart. It can be proven from the result of this study where the result of t-test of post-test of the both group is 3.028. While the result of $t$-table with the level of significance 0,05 is 0,668 . Thus, $t$-test $(3.028)$ is greater than the t-table $(0,668)$. Based on the result of the study, English teachers of SMP Negeri 4 Banda Aceh especially those who teach vocabulary should implement Wall Charts in teaching and learning process because the implementation of the media can increase the students' vocabulary mastery.
\end{abstract}

This is an open access article under the CC-BY-SA license.

\section{INTRODUCTION}

Vocabulary refers to list or a set of words individual speakers of language might used. Hammer (2011) explains that teaching vocabulary does not only teach new meaning of words but also teach how to spell and how to pronounce the words. Teaching vocabulary in the early English learning is very important. Students will find difficulties in learning English if they lack vocabulary. Vocabulary much more than grammar is the key to understand what students hears and reads in school, and to communicate successfully with other people. For this reason it is very important for students to build up a large store of words.

Vocabulary is the most important component language because it affects the four language skills that are listening, speaking, reading, and writing. Related to the importance of vocabulary in language learning, Decarrico in Celce and Murcia (2001), states that vocabulary learning is central to language acquisition, whether the language first, second, or foreign. The reason of why vocabulary is important in learning language is implicitly proposed by McCharty (2010), he said that when people speak of the vocabulary of language people 
are primarily but not exclusively, teaching about the words of that language. Therefore, if vocabulary is related tightly to the learning words of certain language, then it will be central in language learning. For instance, all languages in this world are used by help of words. Words mean onnecting language to the real world. They can be the represent of things in the real life and also used to express feelings of the language user.

Teaching vocabulary for beginners is not easy. Forts (2008) states that teaching vocabulary is quite difficult because there are thousand hundreds words in English. The teacher has to introduce new words and ask the students to practice them, making clear the meanings and the ways in which each can be used. However, many students still get difficulties in increasing their vocabulary mastery.

Bowen (2004) states visual aids are great help stimulating the learner of a foreign language. The students must use their ears as well as their eyes but it is the eye that is primary channel of learning. Good visual materials will help maintains the pace of the lesson and the students' motivation.

Some pictures actually are perfect for the purpose of teaching particularly the vocabulary. There are many types of pictures that are proposed by some expert; one of them is wall chart. Wall Chart is large card displaying diagram or picture. Most wall charts consist of combination of visual and verbal material. While Doff (2008) states that a charts (sometimes called wall chart) is a large sheet of paper or card with writing, picture or diagrams which the teacher can either hold up for the class to see or display on the wall or blackboard used for extended presentation or practice. Wall chart is one of suitable media to teach vocabulary for children. Basically, children love the interesting picture. It makes the teacher easier to give explanation about new vocabulary to young learners.

Bowen (2004) also states that wall chart suitable for pair or group work in intermediate and advance classes and unsuitable for whole class teaching because it is usually complex, with printing too small to be seen by the student from their seats.

The reason of why wall chart is used as the way to enrich the students ${ }^{\text {ee }}$ vocabulary is that young learners as the object of the English language learning are usually interested in a real-life activity. It is also stated by Phillips (2006). "Vocabulary is best learned when the meaning of the word(s) is illustrated, for example by a picture, an action, or a real object. The children should then meet and use the word(s) in relevant contexts, in order to "fix" them in their minds. This helps establish their relationship to other words, so that a vocabulary network is built up.

According to Wingenbach (2010), by wall chart the teacher will get more advantages, because teaching vocabulary to children by using wall chart can; (a) quick way for the students to visualize what the teacher are saying -- numbers, trends, up or down; (b) forceful -- emphasizes main point; (c) convincing -- proves a point, see and hear; (d) compact way to convey information; (e) more interesting than just talk or print (Remember to use as many of the five senses as possible).

In presenting vocabulary, Cross (2009) points out a design to explain an enrich students ${ }^{\text {e }}$ vocabulary using wall chart with step as follow: (1) Sound and the meaning. In this steps, when the teacher teach the word "kite" it is easier for the students if the teacher pronounce the word to them and show them at the same time the object of the picture, that the students, get the meaning immediately. (2) Repetition, in this step, the teacher gets the class to repeat the words that they have learn a few times. It is help the students to practice how to pronouncing words correctly and remembering meaning of words.

Thornbury (2005) states that the time-honored way of memorizinge new material is through repeated rehearsal of the material while it is still in working memory. However, simply repeating an item (the basic of rote learning) seems to have little long-term effect unless some attempt is made to organize the material at the same time. (3) Written Form, the teacher writes the word or sticks the words under picture to show the meaning of the picture. It helps the students to know how to write words of that meaning correctly.

\section{MATERIALS AND METHODS}

The study was conducted from March 5th, 2018 to May 8th, 2018. Wall charts analysis were conducted at SMP Negeri 4 Banda Aceh. . The total population is 115 students who are composed of five classes; class VIII1, class VIII2, class VIII3, class VIII4, and class VIII5In this case, every class was taken 6 students for experimental group and 6 students for control group. Thus, every group consisted 30 students. Therefore, the total sample was 60 students. Choosing students for experimental and control group was conducted randomly. There were two kinds of test; pre-test and post-test. Pre-test was given in order to know the condition of the students before treatment and post-test was given to know the effect of the charts. The writer given 60 questioin to the students that are 20 questions for adjective, 20 questions for nouns and 20 questions for verbs. Where are the question divided by two groups that are 30 question for experimental group who are though vocabulary by using wall chart and 30 questions for the control group who arethough vocabulary without using wall charts.

\section{A. Pre-Test}

Pre-test is given with the intention to find out if there are students who already know about the material to be invited. Pre-test can also be interpreted as activities that conveyed student's knowledge of the material to be delivered, pre-test activities carried out before the given activities are given. The benefit of holding a pre test is to find out the student's initial ability regarding the lesson 
being delivered. By knowing the initial abilities of these students, the teacher will be able to determine how the delivery of lessons will be discussed later.

\section{B. Post-test}

The post-test procedure is a form of questions that are given after the lesson / material submitted. In other words, a post test is a final evaluation when the material taught on that day has been given in which the teacher gives a post test with the intention of whether students have understood and discussed about the material just given that day. The benefit of holding this post test is to get a picture of the abilities obtained after finally from the delivery of lessons. The results of this post test compare with the results of pre tests that have been done so that it will prove far more effective or the results of what has been done, besides being able to verify which parts of the material are still not studied by most students.

\section{RESULTS AND DISCUSSIONS}

\section{Statistical Data Analysis}

There are two kinds of tests, they are pre-test and post-test. Pre-test was given to the students before the teaching learning process, and post-test was given at the last meeting after the teaching learning process. The result of pre-test and post test of experimental group with wall charts by using SPSS 18.0.

Table 1. Statistical Summary of Pre-Test of Experimental Group with Wall Charts and Control Group without Wall

Charts

\begin{tabular}{|c|c|c|c|}
\hline & Pre-Test of EG with Wall Charts & t-test & Pre-Test of CG without Wall Charts \\
\hline N( Number of Students) & 30 & & 30 \\
\hline $\bar{x}($ Mean $)$ & 37.70 & -276 & 37.86 \\
\hline S (Standard Deviation & 5.484 & & 5.008 \\
\hline
\end{tabular}

Based on the statistical summary above, the two mean scores of the pre-test results were calculated for experimental group and control group. Both of them were compared by employing paired sample t-test. As shown in the table above, the mean score of the pre-test of experimental group with peer support is 37.70 . Both mean scores were compared through paired sample t-test with the level of significance 0.05 .

Based on the comparison of the two means, the result of t-table with the level of significance 0.05 is 0.668 and the result of t-test is lower than t-table $(-276<0.668)$. This finding indicates that there is no significance between the result of pre test of the experimental group with wall charts and control group without wall charts. Thus, the conclusion is that the previous students' ability in vocabulary of experimental group with wall charts and control group without wall support is similar.

Table 2. Statistical Summary of the Post-Test of Experimental Group with Wall Charts and Control Group

\begin{tabular}{cccc}
\multicolumn{3}{c}{ without Wall Charts } \\
\hline & $\begin{array}{c}\text { Post -Test of } \\
\text { EG with Wall } \\
\text { Charts }\end{array}$ & & $\begin{array}{c}\text { Post - Test of } \\
\text { CG without } \\
\text { Wall Charts }\end{array}$ \\
\hline N(Number of & 30 & & 30 \\
Students) & & 3.028 & 63.73 \\
$\bar{x}$ (Mean) & 69.06 & & 7.78 \\
S (Standard & 6.20 & & \\
Deviation & & & \\
\hline
\end{tabular}

Based on the statistical summary above, the two mean scores of the post-test results were calculated for experimental group and control group. Both of them were compared by employing paired sample t-test. As shown in the table above, the experimental group and control group. Both of them were compared by employing paired sample t-test. As shown in the table above, the mean score of the post-test of the experimental group with wall charts is 69.06. Both of the mean scores were compared through paired sample t-test with the level of significance 0.05 .

Based on the comparison of the two means, the result of t-table with the level of significance 0.05 is 0.668 , and the result of t-test is higher than t-table $(69.06>0.668)$. The finding indicates that there is a difference between the result of the post-test of the experimental group with wall charts and control group without wall charts. Thus, the conclusion is that the vocabulary skill of experimental group with wall charts and without wall charts after the implementation of wall charts is different.

Table 3. Statistical Summary of the Pre-Test and

Post-Test of Experimental Group with Wall Charts

\begin{tabular}{cccc}
\hline & $\begin{array}{c}\text { Pre -Test of } \\
\text { EG with Wall } \\
\text { Charts }\end{array}$ & t-test & $\begin{array}{c}\text { Post -Test of } \\
\text { EG with Wall } \\
\text { Charts }\end{array}$ \\
\hline N(Number of & 30 & & 30 \\
Students) & & -14.37 & 69.06 \\
$\bar{x}$ (Mean) & 37.70 & & 6.20 \\
S (Standard & 5.484 & \\
Deviation & & \\
\hline
\end{tabular}

The result of $t$-test is used to prove the hypotheses by It aims to find out whether the null hypothesis or the alternative hypothesis is rejected or accepted. The null 
hypothesis is that the students' score before and after the treatment are different. The level of significance is $15 \%$ $(0,05)$ the following probability.. After comparing the two means, the result of $t$-table with the level of significance 0.05 is 0.668 and the result of t-test is lower than t-table $(-14.37<0.668)$

Hence, $\mathrm{Ho}$ is rejected and $\mathrm{Ha}$ is accepted.This indicates that there are significant differences between the two means of pre-test and post-test of experimental group with wall charts.

Table 4 .Statistical Summary of the Pre-Test and

Post-Test of Control Group without Wall Charts

\begin{tabular}{cccc}
\hline & $\begin{array}{c}\text { Pre -Test of } \\
\text { CG without } \\
\text { Wall Charts }\end{array}$ & t-test & $\begin{array}{c}\text { Post - Test of } \\
\text { EG without } \\
\text { Wall Charts }\end{array}$ \\
\hline N (Number of & 30 & & 30 \\
$\quad$ Students) & & -9.001 & 63.73 \\
$\bar{x}$ (Mean) & 37.86 & & 7.78 \\
S (Standard & 5.008 & & \\
Deviation & & \\
\hline
\end{tabular}

Based on the calculation above, the t-test is -9.00 with the level of significance 0.05 . The t-test result is $-9.001<0.668)$, hence $\mathrm{Ho}$ is rejected and $\mathrm{Ha}$ is accepted This indicates that there are no significance differences between the two means of pre-test and post-test of experimental group without wall charts. In other words, there is no progress of the students' mastering vocabulary in control group without wall charts.

Table 5 Mean of Pre-Test and Post-Test of Experimental Group with Wall Charts and Control Group without Wall

\begin{tabular}{cccc}
\multicolumn{3}{c}{ Charts } \\
\hline \multicolumn{2}{c}{ Pre-Test } & \multicolumn{2}{c}{ Post-Test } \\
\hline EG with & CG without & EG with & CG without \\
Wall Charts & Wall Charts & Wall Charts & Wall Charts \\
37.70 & 37.86 & 69.06 & 63.73
\end{tabular}

\section{Discussion}

Before conducting experiment, the writer gave pre-test and the result of pre-test showed that the students, average score of experimental group is 37.70. After the writer gave treatment, the students' average score of experimental group is 69.06. In can be said that the students' ability in mastering vocabulary before treatment was 37.70 and it is not satisfying. Meanwhile after treatment, the students' ability in mastering vocabulary increases 69.06 .

Next, in conducting experimental teaching, at first the writer gave a pre-test to both groups (Experimental and Control Group), the scores obtained by the students showed that there was no significant difference between two groups in which the pre-tests. T-test with level of significanct 0,05. After comparing two means, the result of t-table with the level of significance 0.05 is 0,668 and the result of t-test is lower than t-table $(-276<0,668)$. This find indicates that is no sfnificance between the result of pre test of the experimental group and control group.

Then, the writer used wall charts as media in teaching vocabulary to Experimental Group. After teaching and learning process (tretament), there was a significant difference between the two-groups. It was proven by the result of the post-test in which the post-test scores (69.07) were greater than the pre-test scores (37.70). Next, the statistical analysis indicates that the post-test t-test of both groups is 3.028 . The critical value of t-test for the degree of freedom 0, 668 at the level of significance 0.05 . The result indicates that t-test (3.028) is bigger than t-table $(0,668)$. In other words, the students' scores of experimental group were greater than the students of control group.

\section{CONCLUSSION}

The Students are expected to be useful in the teaching learning process particularly in teaching vocabulary. After reviewing the result of the study and the discussions, some conclusions can be drawn as follows :

1. The second year students' ability of SMP Negeri 4 Banda Aceh in mastering vocabulary before treatment is 37.70. It means the students' ability in mastering preposition is not satisfying.

2. The second year students of SMP Negeri 4 Banda Aceh are interested in learning vocabulary by using wall charts. It is proven that the students enjoy learning vocabulary by using the media.

3. The second year students of SMP Negeri 4 Banda Aceh who are taught vocabulary by using wall charts get higher score than those who are taught without using wall chart. This can be proved from the result of this research where the result of t-test of post-test of the both group 3.028. While the t-table for the degree of freedom 0,05 is .0,668 Thus, t-test (3.028) is greater the t-table (0.668).

4. There is a significant difference between the eighth grade students of SMP Negeri 4 Banda Aceh who are taught vocabulary by using wall chart and those who are taught without using wall chart. Based on the statistical analysis, it is found that the students of experimental group who are taught vocabulary by using wall charts gained better result than the students of controlled group who are taught without using wall charts.

\section{REFERENCES}

Arikunto, Suharsimi. (2002). Research Instrument. Jakarta : Rineka

Bowen, T. et. al. (1994). The Teacher Development Series: Inside Teaching. NewHampshire: Heinemann.

Brewster, J. (2003). The Primary English Teacher's Guide 
New Edition. London.Pearson Editional Limited.

Bromley, K. (2004). Rethinking vocabulary instruction. The Language and LiteracySpectrum, Vol 14, Spring.

Brown, H. D. (2000). Principles of Language Learning and Teaching. New York: A Pearson Education Company.

Burns, A. (1999).Collaborative Action Research for English Language Teachers.Cambridge: Cambridge University Press.

Burton, S.H. (1982). Mastering in Education. New Jersey: Prentice Hall Inc.

Cameron, L. (2001). Teaching Languages to Young Learners. Cambridge:Cambridge University Press.

Caody, J. (1997). Second Language Vocabulary Acquisition. Cambridge: Cambridge University Press.

Dewi, I.K et.al. (2015). Active English A Fun anf Easy English Book for Grade IVof Elementary Schools. Solo: TigaSerangkaiPustakaMandiri.

Doff, A. (1988). Teaching English: A Training Course for Teachers. Cambridge: Cambridge University Press.

Duminy, P.A. (1992). Teaching Practice. Cape Town: Maskew Miller Longman.

Elliot, S et.al. (1996). Educational Psychology: Effective Learning. New York:McGraw-Hill.

Gairns, R. et.al. (1986). Working with words: A Guide to Teaching and LearningVocabulary. USA: Cambridge University Press.

Forts. (2008). An Introduction to English Language Teaching. England: Longman Group Ltd.

Harmer, J. (2011). The practice of English language teaching. London: Longman.

Harris, D. P. (1969). Testing English as a Second Language. USA:McGraw-Hill,Inc.

Haycraft, J. (1978). An Introduction to English Language Teaching. Harlow: Longman.

Hedgcock, J. S. et. al. (2009).Teaching readers of English: Students, texts, and contexts. New York: Routledge.

Hubbard, P. et.al. (1983). A training course for TEFL. Oxford: Oxford UniversityPress.

Lightbown, P. M. et.al. (2006). How Langauges Are Learned, Third Edition. NewYork: Oxford University Press.

Linse, C.T. (2005). Practical English Language Teaching: Young Learners. NewYork: McGrawHill ESL/ELT.

Maharani, S. (2012). Improving Students' Vocabulary Mastery Through the Use ofWall Charts. Surakarta: UniversitasSebelasMaret.

Manurung, H. (2003). Mastering English Competence. Jakarta: Great Media. McCarthy, M. 1989. Vocabulary and Language Teaching. London: Longman.

Melka, F. (1997). Receptive vs. Productive Aspects of Vocabulary.N. Schmitt \& M.McCarthy. Vocabulary:
Description, acquisition and pedagogy. New York: Cambridge UniversityPress.

Nasr, R. T. (1972). Teaching and Learning English. London: Longman group limited.

Nation, P. (1994). New Ways in Teaching Vocabulary. Alexandria, VA: TESOL

Nunan, D. (2003). Practical English Language Teaching, First Edition. NewYork: McGraw Hill.

Read, John. (2000). Assesing Vocabulary. Cambridge: Cambridge University Press.

Richard, J.C. (2001). Curriculum Development in Language Education. Cambridge:Cambridge University Press.

Scott, W. A. et. al. (1990).Teaching English to Children. London New York: Longman.

Scrivener, J. (1994). Learning Teaching : $a$ Guidebook for English LanguageTeachers. Oxford :Heinemam Publishers.

Sugiyono. (2015). Metode Penelitian Pendidikan: Pendekatan Kuantitatif, Kualitatif, dan R\&D. Bandung: Alfabeta.

Thornburry, S. (2002). How to Teach Vocabulary. London. Pearson EducationLimited.

Tim Penyusun. (2015). Cemara Bahasa Inggris untuk SD/MI Kelas 4 Semester 2.Surakarta: Putra Nugraha.

Utami, S.Y. (2014)..Improving Students' Vocabulary Mastery Using Cross word Puzzles for Grade VII of $S M P N 2$ Srandakan in the Academic Year of2013/2014.Yogyakarta: Universitas Negeri Yogyakarta.

Ur, P. (1996). A Course in Language Teaching. Great Britain: Cambridge University Press.

Wingenbach, G. J. (2010). Advantages and Disadvantages to Graphics. Retrieved December 21, 2015, from http://agcj.tamu.edu/howto/GraphicsAdDisad.htm 